\title{
Forum
}

\section{Poverty reduction and biodiversity conservation: rebuilding the bridges}

\author{
Dilys Roe and Joanna Elliott
}

Has biodiversity 'all but disappeared from the global dialogue on sustainable development' as Sanderson \& Redford (2003) fear? Here we explore the poverty reduction imperative that dominates the current agendas of most international development agencies, question the absence of biodiversity conservation from this agenda, and debate the role of the United Nations Millennium Development Goals in building bridges between the two.

Sanderson \& Redford are not wholly correct in lamenting the loss of biodiversity from the sustainable development agenda. Indeed, biodiversity was one of five priority issues singled out for attention at the 2002 World Summit on Sustainable Development. What has happened, however, is that the pace of the sustainable development dialogue has not been fast enough for developing country governments and for international development agencies, and a parallel agenda has emerged in recent years to address an internationally recognized imperative of poverty reduction. This is articulated internationally in the set of eight United Nations Millennium Development Goals (MDGs) and nationally in the World Bank-driven process to develop national poverty reduction strategies in low income countries.

There are many limitations associated with current poverty reduction efforts, as Sanderson \& Redford highlighted. This does not mean that poverty reduction itself is not a laudable objective but rather that the approaches that have been taken to date are not necessarily the most effective (not just in terms of their negative implications for biodiversity conservation, but also for poor people). The lack of attention, not just to biodiversity, but to environmental issues in general, is one such widely perceived limitation (Bojo \& Reddy, 2002). One of the weaknesses of the MDGs is the separation of environment into one of eight goals. Biodiversity conservation is not just the business of the environment goal, rather it underpins the achievement of the others, for example:

Income poverty (MDG 1) Many poor countries have a comparative advantage in that their biodiversity can

Dilys Roe (Corresponding author) Biodiversity and Livelihoods Group, International Institute for Environment and Development, 3 Endsleigh Street, London, WC1H ODD, UK. E-mail dilys.roe@iied.org

Joanna Elliott Consultant Advisor on Wildlife to the UK Department for International Development. E-mail joanna.elliot@ukonline.co.uk

Received 26 January 2004. Accepted 10 February 2004. provide opportunities for jobs, small and micro enterprise, and payments for environmental services. In Africa, tourism (within which nature based tourism is a rapidly growing niche) is a likely source of a significant volume of investment and employment over the coming decade. Wild products can also be a significant source of cash income and employment for poor people, particularly in agriculturally marginal areas. Estimates of the number of people dependent on such products for at least part of their income range from 200 million worldwide to 1 billion just in Asia and the Pacific (van Rijsoort, 2000).

Hunger (MDG 1) Biodiversity underpins food security, and the UN Food and Agriculture Organization (FAO) has emphasized that there are close causal linkages between reducing hunger and the sustainable management of natural resources and ecosystems (FAO, undated). Numerous studies have noted the importance of wild food products, particularly to the poor, for whom securing access to such resources is important for sustaining their livelihoods (e.g. Scoones et al., 1992).

Health (MDGs 4, 5 and 6) Biodiversity provides the base for health care provision worldwide. The majority of the world's modern drugs have their origin in natural products (Koziell \& McNeill, 2002). Many people rely on wild resources for traditional medicines. WHO estimate that up to $80 \%$ of the world population is dependent on these medicines (WHO, IUCN \& WWF, 1993). This is particularly true of the poorest people, who can't afford modern drugs and/or don't have access to clinics and doctors.

Water (MDG 7) It is urban as well as rural populations that are dependent on the goods and services that biodiversity provides. In addition to the direct benefits of food and other goods, conservation of areas such as water catchment forests and flood plains is vital to sustain delivery of ecosystem services such as water supplies and flood control to urban centres.

Moreover, biodiversity conservation provides options for improving the livelihoods of future generations, whereas ecosystem depletion and species extinction reduce the capacity to respond to future stresses such as climate change (Rietbergen et al., 2002).

But the linkages between biodiversity and poverty are generally poorly understood (DFID, 2002) and the potential of biodiversity conservation to contribute to poverty reduction still largely unrecognized by developing country governments and international development 
agencies (DFID, 2002; Koziell \& McNeill, 2002). In part this is because of the fact that despite the particularly high dependence of poor people on biodiversity and other natural resources, environmental goods and services are generally unaccounted for in national statistics and thus not reflected as priorities in national policies (DFID, 2002).

There is clearly much work to be done to bring biodiversity into mainstream international and national poverty reduction efforts. It is here that conservation agencies must take some of the blame, for in a large part the absence of biodiversity conservation from the development agenda is because of their failure to engage effectively and in ways that are seen to be appropriate despite widespread consensus that poverty is a significant underlying threat to conservation (DFID, 2002).

Sanderson \& Redford fear that the Millenium Development Goals may contribute to the 'end of biodiversity', arguing that they downplay conservation. While this is true in that the goals fail to deal properly with the links between biodiversity and poverty, in other respects they directly support a protectionist agenda that has been prominent in international conservation policy. Goal no. 7, Ensure Environmental Sustainability, includes a target to 'Integrate the principles of sustainable development in country policies and programmes and reverse the loss of environmental resources'. The two indicators that have been set for this target emphasize an increase in land area under forest cover or under protection for biodiversity. This presumes that protected areas are the best way to achieve synergy between conservation and development, but this is by no means always so.

While it is true that the protected area approach to conservation can generate significant social, economic and environmental benefits and has undoubtedly helped to ensure the survival of populations of many species and habitats (e.g. Steiner, 2003), it has not been without its costs. In some cases protected areas have failed to sustain the wildlife populations they were designed to protect while at the same time having a negative impact on the food security, livelihoods and cultures of local people (Ghimire \& Pimbert, 1997). McShane (2003) notes that 'As a result, protected areas have often increased poverty amongst the poorest of the poor'.

Just as Sanderson \& Redford fear that the current international frameworks for poverty reduction are dangerous for biodiversity, so the continuous drive to increase protected area coverage rings warning bells for those concerned with sustainable development. Given that protected areas are set to remain the cornerstone of international conservation policy, ensuring their relevance to the poverty reduction agenda implies a need to focus on the quality of existing protected areas rather than striving to create new ones (Steiner, 2003; Roe \&
Hollands, 2004). Quality must be measured in terms of local biodiversity value (for food, medicines, cultural value and environmental services) as well as globally valued megafauna. Vermeulen \& Koziell (2002) note that 'local values... remain poorly documented and poorly represented in the global political arena'.

Traditional forms of protected areas have been statecontrolled, imposed structures. Yet other governance structures exist that build on the traditional knowledge, local management practices and traditional institutions of indigenous peoples and local communities (e.g. Jareith \& Smyth, 2003), and these need to be recognized and integrated into protected area systems. These include community conserved areas, co-managed protected areas (where management is shared among a variety of stakeholders, including government, local people and private landowners) and private parks.

We need to think not just of alternative types of protected areas but also of alternatives to protected areas. Sanderson \& Redford note the potential for linking conservation with changes in commodity production. Indeed, many productive landscapes not only contain large amounts of biodiversity but often have more potential than traditional protected areas and forests for contributing to poverty reduction. Agricultural biodiversity, for example, contributes to productive and environmental sustainability as well as supporting rural development (Pimbert, 1999). Similarly, marine resources play a significant role in contributing to food security and sustainable local livelihoods (one billion people in Asia rely on fish for their primary source of protein, and the global fishing industry employs c. 200 million people (IUCN, 2003)). The latest calculation of protected area coverage (Chape et al, 2003) notes, however, that only 1.7 million $\mathrm{km}^{2}$ (or $0.5 \%$ ) of ocean area is protected (of which $20 \%$ is the Great Barrier Reef of Australia).

Sanderson \& Redford's call for 'partnerships between conservationists and developmentalists' is laudable and both sides need to recognize their respective strengths and weaknesses. Just as there are conceptual and operational flaws, as Sanderson \& Redford point out, in international thinking on effective approaches to poverty reduction, so there are serious equity issues associated with the current Northern-centric approach to biodiversity conservation, and protected areas in particular. The language of 'conservation' rather than 'protection' as embodied in the Convention on Biological Diversity accepts that there are trade-offs. It will take good governance, effective global mechanisms for paying for global biodiversity values, and innovative approaches to conservation that benefit poor people to encourage and enable developing countries to safeguard their global biodiversity assets as well as ensure their poorest citizens 
have fair and reasonable standards of living (as is embodied in the concept of 'pro-poor conservation' promoted at last year's World Parks Congress (Roe \& Elliott, 2003; Roe et al., 2003; Poverty \& Conservation Working Group, 2003)).

Just as biodiversity should not 'pay the price for development yet again', as Sanderson \& Redford fear it may, so poor people should not pay the price for biodiversity protection.

\section{References}

Bojo, J. \& Reddy, R.C. (2002) Poverty Reduction Strategies and Environment. Environment Department Paper no 86, World Bank, Washington, DC, USA.

Chape, S., Blythe, S., Fish, L., Forx, P. \& Spalding, M. (2003) 2003 United Nations List of Protected Areas. IUCN and UNEP-WCMC, Gland, Switzerland and Cambridge, UK.

DFID (2002) Wildlife and Poverty Study. DFID Livestock and Wildlife Advisory Group, London, UK.

FAO (undated) FAO's Contribution to Achievement of the Development Goals of the United Nations Millennium Declaration. Http:/ / www.fao.org/es/ESS/mdg_kit/ contrib.asp [accessed 16 January 2004].

Ghimire, K. \& Pimbert, M. (1997) Social Change and Conservation. Earthscan, London, UK.

IUCN (2003) Sustainable Livelihoods. Media Brief for the World Parks Congress. IUCN, Gland, Switzerland.

Jareith, H. \& Smyth, D. (2003) Innovative Governance: Indigenous Peoples, Local Communities and Protected Areas. Ane Books, New Delhi, India.

Koziell, I. \& McNeill, C. (2002) Building on Hidden Opportunities to Achieve the Millennium Development Goals: Poverty Reduction through Conservation and Sustainable Use of Biodiversity. WSSD Opinion Paper, International Institute for Environment and Development, London, UK.

McShane, T. (2003) Protected areas and poverty. In Community Empowerment for Conservation. Special edition of Policy Matters, 12, 52-53.
Pimbert, M. (1999) Sustaining the Multiple Functions of Agricultural Biodiversity. Gatekeeper Series No 88. IIED, London, UK.

Poverty and Conservation Working Group (2003) Pro-Poor Conservation: Harnessing Conservation for Poverty Reduction. Unpublished Discussion Paper. International Institute for Environment and Development, London, UK.

Rietbergen, S., Bishop, J. \& Mainka, S. (2002) Ecosystem Conservation: A Neglected Tool for Poverty Reduction. WSSD Opinion Paper. International Institute for Environment and Development, London, UK.

Roe, D. \& Elliott, J. (2003) Pro-poor conservation: The elusive win-win for conservation and poverty reduction? Paper presented at the 5th World Parks Congress, Durban, South Africa.

Roe, D., Hutton, J., Elliott, J., Chitepo, K. \& Saruchera, M. (2003) In pursuit of pro-poor conservation: changing narratives or more? In Community Empowerment for Conservation. Special edition of Policy Matters, 12, 87-91.

Roe, D. \& Hollands, M. (2004) Protected Areas: How Much is Enough? Sustainable Development Opinion Series, International Institute for Environment and Development, London, UK.

Sanderson, S. \& Redford, K. (2003) Contested relationships between biodiversity conservation and poverty alleviation. Oryx, 37, 389-390.

Scoones, I., Melnyk, M. \& Pretty, J.N. (1992) The Hidden Harvest. Wild Foods and Agricultural Systems. A Literature Review and Annotated Bibliography. International Institute for Environment and Development, London, UK.

Steiner, A. (2003). Trouble in paradise. New Scientist, 180 (2417), 21.

van Rijsoort, J. (2000) Non-Timber Forest Products (NTFPs): Their Role in Sustainable Forest Management in the Tropics. Theme Studies Series. National Reference Centre for Nature Management, Wageningen, The Netherlands.

Vermeulen, S. \& Koziell, I. (2002) Integrating Global and Local Values. A Review of Biodiversity Assessment. Natural Resource Issues Paper. International Institute for Environment and Development, London, UK.

WHO, IUCN \& WWF (1993) Guidelines on the Conservation of Medicinal Plants. IUCN, Gland, Switzerland. 